\title{
Robert Kołodziej
}

Uniwersytet Wrocławski

kolodziej69@op.pl

\section{Udział Potockich w obradach sejmowych w czasach Jana III Sobieskiego}

\begin{abstract}
Abst rakt: Celem artykułu jest prześledzenie działalności politycznej członków rodu Potockich w czasie panowania Jana III Sobieskiego. Analiza dotyczy aktywności parlamentarnej Potockich, którzy pełnili w tym okresie funkcje posłów oraz senatorów. W przypadku posłów obejmuje rozpoznanie sejmików, z których wybierani byli na funkcje poselskie, oraz przejawy ich aktywności na forum sejmu. W przypadku senatorów dotyczy ich odpowiedzi na deliberatoria przedsejmowe, wygłoszone wota senatorskie, udział w obradach sejmików przedsejmowych i frekwencję na sejmach. Dzięki analizie można spróbować odpowiedzieć na pytanie, na ile aktywność sejmowa przekładała się na awanse i kariery polityczne.
\end{abstract}

Słowa kluczowe: Potoccy, Jan III Sobieski, posłowie, senatorowie, sejmy, sejmiki

Jednym z najważniejszych obszarów działalności politycznej w dawnej Rzeczypospolitej było uczestnictwo w obradach sejmowych. Ponieważ otrzymanie na sejmiku funkcji posła sejmowego było ważnym elementem kariery, wszystkie liczące się w kraju rody starały się forsować swoich przedstawicieli do tej godności. Od początków XVII wieku znaczenie rodu Potockich w Polsce zaczęło systematycznie rosnąć, nie może więc dziwić fakt, że coraz więcej Potockich pojawiało się wśród aktywnych członków izby poselskiej. O ile w całym XVI wieku wydawcom spisu posłów koronnych udało się ustalić jedynie sześciu przedstawicieli tego rodu ${ }^{1}$, o tyle za panowania Władysława IV, według ustaleń Jana Dzięgielewskiego, było ich już siedmiu, a na sejmy czasów Jana Kazimierza posłowało aż trzynastu Potockich ${ }^{2}$. Tendencja wzrostowa w tym zakresie utrzymała się w krótkim okresie panowania

\footnotetext{
${ }^{1}$ Posłowie ziemscy koronni 1493-1600. Red. I. KaniewsKa. Warszawa 2013, passim.

2 J. DzIĘGIELEWSKI: Izba poselska w systemie władzy Rzeczypospolitej w czasach Władysława IV. Warszawa 1992, s. 176; S. Ochmann-Staniszewska, Z. STANiSzewski: Sejm Rzeczypospolitej za panowania Jana Kazimierza Wazy. Prawo - doktryna - praktyka. T. 2. Wrocław 2001, s. 364, 393.
} 
Michała Korybuta, kiedy to dziewięciu przedstawicieli rodu pełniło funkcje poselskie, a dodatkowo Feliks (Szczęsny) Potocki był marszałkiem sejmu elekcyjnego $1669 \mathrm{roku}^{3}$. Niebagatelną rolę polityczną odgrywali Potoccy w drugiej połowie XVII wieku, niemałe były ich aspiracje rodowe. Nie dziwi więc ich aktywny udział w życiu publicznym kraju — zarówno w skali lokalnej (a więc na sejmikach ziemskich), jak i ogólnokrajowej. Również w czasach Jana III wśród posłów znaleźć można licznych Potockich. Funkcję poselską w latach 1676-1695, podczas kolejnych dwunastu sejmów, pełniło dziesięciu z nich. Dziewięciu to Potoccy herbu Pilawa, jeden herbu Lubicz ${ }^{4}$. Posłowali oni oczywiście z sejmików ze wschodniej Małopolski, a więc z miejsca, gdzie posiadali majątki, byli posesjonatami i mogli prowadzić aktywną działalność polityczną. Często reprezentowali sejmik halicki województwa ruskiego oraz obradujący we Lwowie egzulancki sejmik podolski. Poza tym można spotkać Potockich jako reprezentantów wszystkich trzech sejmików egzulanckich obradujących we Włodzimierzu (bracławskiego, kijowskiego i czernihowskiego), a także sejmików bełskiego oraz chełmskiego ${ }^{5}$.

Najczęściej funkcję poselską w omawianym czasie pełnił Stefan Potocki, syn Pawła, kasztelana kamienieckiego. Wybrany był on na pięć sejmów w latach 1688-1695 (nie posłował jedynie na sejm warszawski 1688-1689). Czterokrotnie posłował z sejmiku podolskiego, jedynie w 1692 roku wybrano go z sejmiku halickiego ${ }^{6}$. Nieznana jest przyczyna takiej decyzji, nie była nią raczej obawa przed zerwaniem zjazdu Podolan, który zakończył się szczęśliwie i, co ciekawe, funkcją poselską obdarzył innego Potockiego - Józefa, starostę halickiego, późniejszego hetmana wielkiego koronnego i kasztelana krakowskiego (była to zresztą jedyna funkcja poselska, jaką uzyskał w czasach Jana III). Dwóch Potockich posłowało na ówczesne sejmy czterokrotnie. Pierwszy z nich to starszy brat Stefana, Aleksander Potocki, późniejszy kasztelan kamieniecki i wojewoda smoleński, który trzy razy wybierany był w Haliczu, raz wybrany został przez podolski sejmik egzulancki ${ }^{7}$. Czterokrotnie posłem był również Franciszek Potocki, starosta owrucki, reprezentując cały czas środowisko egzulanckie. Trzykrotnie wybrany został posłem na

${ }^{3}$ L.A. Wierzbicki: Marszałkowie i parlamentarzyści. Studia z dziejów sejmu polskiego w XVII wieku. Warszawa 2014, s. 72.

${ }^{4}$ Franciszek Potocki, starosta owrucki, zob. K. Niesiecki: Herbarz polski. T. 7. Wyd. J.N. BoBROWICZ. Lipsk 1841, s. 426.

${ }^{5}$ Źródła dotyczące uczestnictwa Potockich w sejmach w charakterze posłów i senatorów omówiono w innym miejscu, zob. R. KoŁodzIEJ: „Ostatni wolności naszej klejnot”. Sejm Rzeczypospolitej za panowania Jana III Sobieskiego. Poznań 2014; materiały te uzupełniono o informacje z ksiąg grodzkich włodzimierskich znajdujących się w Centralnij dierżawnij istoricznij archiw Ukraini (dalej: CDIAU) Kijów, f. 28.

${ }^{6}$ R. KoŁodziej: „Ostatni wolności naszej klejnot”..., s. 629.

${ }^{7}$ Reprezentował sejmik halicki na sejmach w latach 1685, 1688 (sejm grodzieński) i 1690; z sejmiku podolskiego posłował do Grodna na sejm z lat 1692-1693, zob. R. KoŁodziej: „Ostatni wolności naszej klejnot"..., s. 628. 
sejmiku bracławskim (na sejm grodzieński $1678-1679^{8}$ oraz na sejmy warszawskie w $1685^{9}$ i $1693 \mathrm{roku}^{10}$ ). Na sejm grodzieński z lat $1692-1693$ wybrano go posłem na sejmiku kijowskim ${ }^{11}$.

Dwóch spośród Potockich pełniło funkcję poselską trzykrotnie. Pierwszy z nich to Dominik Potocki, starosta chmielnicki i podkomorzy halicki, tuż przed śmiercią w 1683 roku mianowany podskarbim nadwornym koronnym, najmłodszy syn hetmana wielkiego Mikołaja Potockiego. Posłował on wyłącznie z sejmiku halickiego ${ }^{12}$. Trzykrotnie z Bełza i Chełmu posłował Michał Potocki, starosta krasnostawski ${ }^{13}$. Dwukrotnie posłami z Halicza byli: Stanisław Potocki, starosta kołomyjski (który w 1683 roku zginął w bitwie pod Wiedniem) ${ }^{14}$, Stefan Potocki, łowczy koronny (późniejszy wojewoda bełski), syn wojewody bracławskiego Jana Potockiego ${ }^{15}$. Dwukrotnym posłem był również Józef Felicjan Potocki, starosta ropczycki, syn Feliksa, który na sejm warszawski 1693 roku przybył jako reprezentant szlachty podolskiej ${ }^{16}$, a na sejm 1695 roku - jako przedstawiciel egzulantów czernihowskich ${ }^{17}$.

Wreszcie pojedyncze poselstwa zanotowały dwie osoby. Z sejmiku bracławskiego posłował Jan Karol Potocki, tamtejszy podkomorzy (sejm koronacyjny 1676 roku $)^{18}$, a sejmik podolski wybrał na posła wspomnianego Józefa Potockiego, starostę halickiego ${ }^{19}$.

${ }^{8}$ Ibidem.

${ }^{9}$ CDIAU, f. 28, ks. 130, k. 642v, Instrukcja bracławska na sejm 1685 r.

${ }^{10}$ Ibidem, ks. 138, k. 1058, Instrukcja bracławska na sejm 1693 r.

${ }^{11}$ Ibidem, ks. 137, k. 1156, Instrukcja kijowska na sejm 1692-1693 r.

${ }_{12}$ Reprezentował swoją ziemię na sejmach w latach 1676, 1681 oraz 1683, zob. R. KoŁodziej: „Ostatni wolności naszej klejnot”..., s. 628. Jan III oceniał go jako znakomitego żołnierza, ale i dobrego gospodarza i poczciwego człowieka, zob. A. Przy воś: Potocki Dominik h. Pilawa (zm. 1683). W: Polski słownik biograficzny (dalej: PSB). T. 27. Wrocław-Warszawa 1983, s. 803.

${ }_{13}$ Jako poseł bełski obecny był na sejmie 1690 roku, z Chełma posłował w latach 1692-1693; nie udało się ustalić, z którego sejmiku posłował w 1695 roku, choć wiadomo, że był wówczas na sejmie, zob. R. KoŁodziej: „Ostatni wolności naszej klejnot”..., s. 628; w przyszłości Michał Potocki awansował na pisarstwo wielkie koronne, a następnie na województwo wołyńskie, zob. A. Link-Lenczowski, E. Szklarska: Potocki Michał (zm. 1749). W: PSB. T. 28. Wrocław 1984-1985, s. 97-101.

${ }_{14}$ Posłował na sejmy w latach 1681 oraz 1683, zob. R. KoŁodzIEj: „Ostatni wolności naszej klejnot”..., s. 629; M. WAGner: Potocki Stanisław h. Pilawa (1659-1683). W: PSB. T. 27..., s. 153-154.

15 Posłował na sejmy warszawskie w latach 1685 i 1688-1689, zob. R. Ko£odziej: „Ostatni wolności naszej klejnot”..., s. 629; zob. A. Link-Lenczowski: Potocki Stefan h. Pilawa (zm. 1726). W: PSB. T. $28 \ldots$, s. $177-180$.

${ }^{16}$ R. KoŁodziej: „Ostatni wolności naszej klejnot”..., s. 628.

${ }_{17}$ CDIAU, f. 28, ks. 139, k. 928, Instrukcja sejmiku czernihowskiego na sejm 1695 r.

18 R. KoŁodziej: „Ostatni wolności naszej klejnot”..., s. 628.

19 A. Link-Lenczowski błędnie podał, że J.F. Potocki posłował z Bełza, zob. PSB. T. 28..., s. 58; na skorygowanie ustaleń pozwoliło wydanie przez Jarosława Stolickiego akt podolskich, zob. Akta sejmikowe województwa podolskiego in hostico 1672-1698. Wyd. J. STOLICKI. Kraków 2002, s. 179. 
Jak widać z tego zestawienia, Potoccy byli wybierani na funkcje poselskie stosunkowo często, bo aż dwadzieścia siedem razy. Jednak nie wydaje się, aby w tym przypadku ilość miała przełożenie na jakość. W dyskusjach sejmowych Potoccy nie byli specjalnie widoczni, rzadko zabierali głos, byli mało dostrzegani przez autorów diariuszy sejmowych. Z pewnością nie byli pierwszoplanowymi postaciami sejmów w omawianym okresie. Można nawet odnieść wrażenie, że częściej pojawiali się jako negatywni bohaterowie obrad. Dominik Potocki podczas sejmu koronacyjnego w 1676 roku, zdaniem Jarosława Stolickiego, bardzo szczęśliwie uniknął sądu za dezercję, jako jeden z dowódców, który nie stawił się ze swoim oddziałem w obozie królewskim ${ }^{20}$. Szczególnie negatywnie wyróżniał się jednak Michał Potocki, starosta krasnostawski, najstarszy syn Szczęsnego Potockiego, wojewody krakowskiego. Wszystkie trzy jego posłowania zostały odnotowane przez obserwatorów, ale nie były to uwagi, które przynosiły chlubę młodemu magnatowi. W 1690 roku o mało nie doprowadził on do zerwania niemal już zakończonego sejmu, gdy demonstracyjnie wyszedł z izby poselskiej, wstrzymując jej obrady. Zdaniem brandenburskiego dyplomaty Gottfrieda Wernera, działanie Potockiego było spowodowane pominięciem go przez króla $w$ wakansach ${ }^{21}$. Ostatecznie udało się go ściągnąć z powrotem do izby, przy niemałym udziale samego monarchy, który podjął się mediacji. Nie bez znaczenia były również w tym przypadku naciski innych członków rodu. Po urażonego Michała Potockiego wysłano bowiem, jak zapisał autor diariusza sejmowego, „księcia [Józefa] Potockiego, stryjecznego brata jego”22. Kolejne kłopoty z młodym i awanturniczym Michałem Potockim miały miejsce trzy lata później, podczas sejmu grodzieńskiego z lat 1692-1693. W izbie poselskiej, jeszcze na etapie obrad rozłączonych, udało się spisać kilkanaście projektów konstytucji. Gdy pojawiła się konieczność połączenia izb i rozpoczęcia konkluzji, zaoponowali posłowie krakowscy i wiele czasu zajęło przekonanie ich, aby odstąpili od swoich pretensji. Gdy wreszcie udało się przełamać opór krakowian, ze sprzeciwem wystąpił posłujący wówczas z Chełma starosta krasnostawski, blokując połączenie się izb i opóźniając konkluzję․ Dodać należy na marginesie, że stało się to jedną z przyczyn zerwania sejmu, ponieważ kilka dni później posłowie łęczyccy nie zezwolili na prolongowanie obrad i wyjechali z Grodna. Z kolei podczas ostatniego

${ }^{20}$ J. Sтоціскі: Wobec wolności i króla. Działalność polityczna szlachty ruskiej, ukrainnej i wotyńskiej w latach 1673-1683. Kraków 2007, s. 124.

${ }^{21}$ Geheimes Staatsarchiv Preussischer Kulturbesitz, Berlin-Dahlem (dalej: GStPK), I HA, Rep. 9, 27.n.1, k. 48-51, [Relacja Gottfrieda Wernera], Warszawa 7/17 III 1690.

${ }^{22}$ Rosyjska Nacjonalna Biblioteka, Sankt-Petersburg, f. 957, Pol.F.IV, 276, k. 99v, Sejm walny 1690 warszawski.

${ }^{23}$ Archiwum Główne Akt Dawnych w Warszawie (dalej: AGAD), AR, dz. VI, II-51, s. 27, Sejm walny sześćniedzielny grodzieński sub auspiciis najjaśniejszego KJM Jana III za dyrekcyjej izby poselskiej wielmożnego jm. pana Kryszpina pisarza polnego W. Ks. Lit. w roku 1692 die 31 decembris zaczęty. 
sejmu odbytego za życia króla Jana III, zwołanego na 1695 rok, Michał Potocki stał się głównym aktorem skandalu obyczajowego, do jakiego doszło na dworze królewskim. Tak opisuje to wydarzenie nieoceniony dla badaczy omawianych czasów pamiętnikarz Kazimierz Sarnecki:

w wieczór [...] pan starosta krasnostawski upiwszy się, bardzo bestyjalskie na pokojach królowej jm. czynił akcyje, kiedy wziąwszy naturalia ad manus, nie tylko mężatkom, ale i pannom one prezentował ad ocula i o stół nimi kilka razy uderzył, do jm. pani podkomorzynej koronnej przyszedłszy, tak się z nią mocował, że na palcu jej obrączki połomał, drugie od niego ledwo pouciekały ${ }^{24}$.

O ile nie wyróżniali się Potoccy konstruktywną pracą na rzecz kraju, o tyle nie zapominali o załatwianiu spraw związanych $\mathrm{z}$ interesem rodzinnym (co nie było zresztą cechą charakterystyczną wyłącznie dla tego rodu). Potoccy potrafili być w swoich sprawach majątkowych bardzo skuteczni. Na sejmie 1681 roku, niewątpliwie pod ich wpływem, posłowie przygotowali konstytucję, która miała zrekompensować dzieciom zmarłego w 1675 roku Pawła Potockiego, kasztelana kamienieckiego ${ }^{25}$, straty, jakie ponieśli w wyniku delimitacji granicy z Turcją po utracie przez Rzeczpospolitą Podola. Ponieważ sejm został zerwany, sama konstytucja przepadła. Potrafili jednak Potoccy wpłynąć na króla, aby temat powrócił na posejmowej radzie senatu, która w swojej konkluzji postanowiła rekompensatę dla kasztelaniców kamienieckich w wysokości 4000 zł rocznie, które wypłacać im miał podskarbi koronny ${ }^{26}$. Co warte podkreślenia, na kolejnym sejmie uchwałę rady senatu utrzymano i potwierdzono specjalną konstytucją ${ }^{27}$. Było to o tyle interesujące, że szlachta raczej niechętnie przyjmowała decyzje rad senatu dotyczące wydatkowania pieniędzy.

Z tego krótkiego omówienia wynika, że wkład Potockich w prace izby poselskiej był raczej skromny. Znacznie bardziej konstruktywnie przedstawiał się w badanym okresie udział w pracach sejmowych senatorów z rodu Potockich. W momencie elekcji Jana III funkcje senatorskie pełniło czterech $\mathrm{z}$ nich, jednak Jan, wojewoda

${ }^{24}$ K. Sarnecki: Pamiętniki z czasów Jana Sobieskiego. Diariusz i relacje z lat 1691-1696. Oprac. J. Woliński. Wrocław 1958, s. 181.

${ }^{25}$ Paweł Potocki pozostawił z dwóch małżeństw dziesięcioro dzieci, zob. M. NAGIELsKı: Potocki Pawet h. Pilawa (zm. 1675). W: PSB. T. 28..., s. 119.

${ }^{26}$ AGAD, APP, 163 a, t. 3, s. 217, Senatus consulta, Warszawa 31 V 1681.

27 Approbacya skryptu urodz. kasztellanicom kamienieckim. W: Volumina Legum. T. 5. Wyd. J. Oнryzкo. Petersburg 1860, s. 672-673; potwierdzenie to nastąpiło być może dzięki wstawiennictwu posłów bełskich, którzy na sejmiku przed sejmem 1683 roku wpisali w instrukcję punkt o wynagrodzeniu kasztelaniców podolskich, zob. CDIAU Lwów, f. 1, op. 1, nr 275; s. 1455, Instrukcja sejmiku bełskiego posłom na sejm, Bełz 16 grudnia $1682 \mathrm{r}$. 
bracławski, oraz jego brat Paweł, kasztelan kamieniecki, zmarli w 1675 roku, a więc jeszcze przed sejmem koronacyjnym. $Z$ tego powodu tylko dwóch przedstawicieli rodu miało szansę brać udział jako senatorowie w sejmach w omawianym czasie. Byli to bracia: Feliks (Szczęsny) i Jędrzej (Andrzej) Potoccy, synowie hetmana Stanisława Rewery Potockiego. Obu z pewnością należy zaliczyć do czołowych przedstawicieli życia politycznego w kraju.

Jędrzej Potocki od 1676 do 1691 roku, czyli w okresie, kiedy sprawował urzędy senatorskie (kolejno wojewody kijowskiego, krakowskiego i kasztelana krakowskiego), opuścił tylko dwa sejmy. Raczej nieprzypadkowo obie nieobecności przypadły na grodzieńską kadencję, w latach $1678-1679$ oraz w 1688 roku. Na obu sejmach pojawiło się niewielu senatorów koronnych, wystraszonych fatalną sytuacją bytową i horrendalnie wysokimi cenami gospód. Można byłoby więc przyjąć, że Jędrzej Potocki był senatorem bardzo sumiennym. Jednak trzeba mieć na uwadze, że nie przyjeżdżał na sejmy punktualnie i tylko raz, w 1685 roku, udało mu się zdążyć na - mocno wówczas spóźnione - wota senatorskie. Co więcej, w 1683 roku Potocki przyjechał na obrady do Warszawy niechętnie i tylko na wyraźne życzenie monarchy. Był przy tym jednak usprawiedliwiony, ponieważ jego syn wówczas ciężko chorował ${ }^{28}$. Jednak nie można odmówić Jędrzejowi Potockiemu zainteresowania sprawami państwa, o czym świadczą zachowane odpowiedzi na królewskie deliberatoria. W przeciwieństwie do niektórych senatorów, nie ograniczał się w nich jedynie do grzecznościowych uwag, ale proponował konkretne rozwiązania i wysuwał ciekawe propozycje związane z usprawnieniem pracy sejmu ${ }^{29}$. Był Potocki przeciwnikiem prolongat sejmowych i podnosił, że wielomiesięczne sejmowanie ma negatywny wpływ nie tylko na możliwości prowadzenia działań wojennych przeciw Imperium Osmańskiemu, lecz także na zdrowie króla. Zwracał również uwagę na egzekucję uchwał sejmowych, narzekając na negatywną rolę sejmików relacyjnych, i apelował, ,żeby sejmiki uchwały sejmowej non invalident, ale ad mentem Rzptej onę exequantur i podatki na zapłatę wojska wydawały" ${ }^{30}$. W trosce o stan finansów państwa domagał się, aby zgodnie z prawem nie dopuszczać do funkcji poselskiej tych, „którzy podatkowe pieniądze po województwach mają w swojej dyspozycyjej" ${ }^{\prime 3}$. Przede wszystkim jednak Jędrzej Potocki zajmował się podczas sejmów sprawami wojska, aktywnie uczestnicząc w pracach organów sejmowych do tego powołanych: deputacji do hiberny, deputacji do spraw obrony oraz oczywiście do wojska, w których $\mathrm{z}$ urzędu jako hetman przedstawiał sprawozdania z działań wojennych. Nie zapominał podczas obrad o interesach żołnierzy, między innymi wstawiał się za posłami wojskowymi na sejm, prosząc króla, aby

\footnotetext{
${ }^{28}$ AGAD, APP, 315, s. 44, Jędrzej Potocki do podczaszego wiskiego, Stanisławów 201683.

${ }^{29}$ Ibidem, s. 11-12, 15-17, 21-22, 28, Listy Jędrzeja Potockiego.

${ }^{30}$ Ibidem, s. 21-22, Jędrzej Potocki do króla, Oteny 17 X 1689.

${ }^{31}$ Ibidem, s. 11-12, Jędrzej Potocki do króla, Stanisławów 2 X 1688.
} 
„odnieśli ukontentowanie" ${ }^{32}$. Na rzecz swoich podkomendnych pracował również na dworze. Na przykład w 1687 roku prosił regenta kancelarii koronnej i zaufanego królewskiego Stanisława Szczukę, aby posłem królewskim na przedsejmowy sejmik łęczycki uczynić obersztlejtnanta dragońskiego [Franciszka?] Elerta, a legatem do Proszowic - Opackiego ${ }^{33}$.

Jędrzej Potocki pracował również intensywnie na sejmikach przedsejmowych i relacyjnych. Przede wszystkim w obszarze jego wpływów leżał sejmik halicki. Król wielokrotnie kontaktował się z kasztelanem krakowskim, konsultując z nim kwestie związane z tym właśnie sejmikiem ${ }^{34}$. Potocki miał w ziemi halickiej wielu zaufanych, którzy pracowali dla niego zarówno podczas zjazdów, jak i w trakcie ich przygotowywania. Podczas kampanii przedsejmowej pod koniec 1688 roku donieśli oni kasztelanowi krakowskiemu o niepokojach wśród okolicznej szlachty, „że uniwersał na sejmik przyszły ma być z pieczęcią pokojową przysłany”. Sam Potocki tłumaczył się, że wprawdzie uniwersał przeszedł przez jego ręce i on sam oddał go do grodu, jednak nie zwrócił uwagi na pieczęć, „bom na ten czas ciężko chorował”. Prosił z tego powodu Stanisława Szczukę, regenta kancelarii koronnej, o szybkie przysłanie kolejnego uniwersału, tym razem z pieczęcią koronną, „aby ten pierwszy uniwersał nie zatrudnił et non invalidet sejmiku" ${ }^{35}$. Pracował Potocki również na innych sejmikach, jak choćby na zjeździe proszowickim, gdzie pilnował, aby szlachta wywiązywała się z ustaleń podatkowych sejmu ${ }^{36}$.

Jędrzej Potocki nie należał do opozycji antykrólewskiej, zaliczano go raczej do senatorów niezależnych, choć w wielu kwestiach wyświadczał królowi przysługi i popierał jego działania. O tym, że był liczącą się postacią polityczną, świadczy choćby fakt, że podszywali się pod niego paszkwilanci, produkujący ulotną literaturę polityczną. Takim dziełkiem był krążący po kraju w 1684 roku paszkwil antykrólewski, „List jm. pana krakowskiego Jędrzeja Potockiego do księcia jm. arcybiskupa gnieźnieńskiego Stefana Wydżgi pisany ze Lwowa, d. 28 decembris 1684”37.

${ }^{32}$ Ibidem, s. 15-17, Jędrzej Potocki do króla, b.m. i b.d. [1688].

${ }^{33}$ Biblioteka Książąt Czartoryskich, rkps 2715, s. 199, J. Potocki, kaszt. krakowski do [S. Szczuki], w Bursztynie 27 IX 1687.

${ }^{34}$ J. StOLICKi: Wobec wolności..., s. 105.

${ }_{35}$ AGAD, APP, 315, s. 105, Jędrzej Potocki do [Stanisława Szczuki], Stanisławów 21 X 1688.

36 AGAD, APP, 163, t. 2, s. 465-467, Jędrzej Potocki do S. Szczuki regenta kor., w Bejscach [?] $3 \mathrm{~V} 1687$.

${ }^{37}$ Pomniki dziejów Polski wieku siedemnastego. T. 1. Wyd. A. Podgórski. Wrocław 1840, s. 214; paszkwil ten był jednym z elementów sfabrykowanej przez opozycję i masowo kolportowanej po kraju fałszywej korespondencji między J. Potockim a prymasem J. Wydżgą, zob. B. Górna: Antykrólewska propaganda opozycji (od bitwy wiedeńskiej do sejmu 1685 roku). „Śląski Kwartalnik Historyczny Sobótka" 1996, 51, nr 1-3, s. 147-152; szczegółową analizę pism zob. w: A. CzARNIECKA: Nikt nie słucha mnie za życia... Jan III Sobieski w walce z opozycyjna propaganda (16841696). Warszawa 2009, s. 120-129. 
Drugim senatorem z rodu Potockich był Feliks (Szczęsny), kolejno wojewoda sieradzki i krakowski ${ }^{38}$, po śmierci brata Jędrzeja obdarzony w 1692 roku urzędem hetmańskim. Feliks, podobnie jak jego brat, starał się pracować dla króla na sejmikach. Sobieski prosił go przede wszystkim o usługi na sejmiku bełskim, ale jego starania miały różny skutek. W grudniu 1694 roku nie potrafił na sejmiku przedsejmowym przeciwdziałać opozycji, która zerwała obrady, nie dopuszczając nawet do przeczytania uniwersału króla i przyjęcia jego posła ${ }^{39}$. Feliks Potocki regularnie bywał na sejmach i, podobnie jak brat, konsekwentnie opuszczał zjazdy organizowane w Grodnie, na których nie pojawił się ani razu. Od 1676 do 1690 roku był za to na wszystkich sejmach odbywających się w Koronie. Na dwóch ostatnich sejmach za życia Sobieskiego był nieobecny, ale nie może to zbytnio dziwić. Sejm z grudnia 1693 roku zakończył się z powodu choroby króla po jednym dniu, sejm z 1695 roku był z kolei pasmem nieustających sporów i awantur i nie dawano mu najmniejszych szans na szczęśliwe zakończenie. Szczęsny Potocki trzykrotnie wygłosił wotum sejmowe: w latach 1676, 1677 i 1685. Podobnie jak brat Jędrzej, odpowiadał też regularnie na deliberatoria, o czym informował zaufanego królewskiego Stanisława Szczukę ${ }^{40}$. Same odpowiedzi nie są niestety znane.

Jego stosunek do króla jest trudny do oceny. Zdaje się, że — podobnie jak brat starał się zachować niezależność. Wprawdzie często spotykał się z królem, również na stopie prywatnej, i niekiedy bardzo mocno popierał jego plany. Tak było na przykład w 1689 roku po tak zwanym ,afroncie berlińskim” i niedoszłym małżeństwie Jakuba Sobieskiego z księżniczką Ludwiką Karoliną, córką Bogusława Radziwiłła. Potocki na sejmie w swojej mowie bardzo ostro skrytykował działania księżniczki i zadeklarował, że dopóki nie zostanie uchwalona konstytucja o konfiskacie dóbr Ludwiki Karoliny, on na nic nie pozwoli i wyjdzie z protestacją ${ }^{41}$. Ostatecznie groźby swojej nie spełnił, ale sam sejm i tak został zerwany. $Z$ drugiej jednak strony wojewoda krakowski nie zapominał dbać o popularność u szlachty. W takich kategoriach należy chyba rozpatrywać jego działania po sejmie 1690 roku, gdy wniósł protestację przeciw wielu uchwalonym wówczas konstytucjom, rozsyłając ją po sejmikach $\mathrm{w}$ takim terminie, aby szlachta otrzymała ją wraz z drukowanymi konstytucjami ${ }^{42}$. Głos wojewody w sprawie fałszerstw, jakie miały mieć miejsce po sejmie 1690 roku,

${ }^{38}$ Informacje, jakoby Feliks Potocki był również przez kilka miesięcy wojewodą kijowskim, zostały uznane za nieprawdziwe, zob. Urzędnicy województwa kijowskiego i czernihowskiego XVIXVIII wieku. Spisy. op. E. Janas, W. KŁaCzewsKi. Kórnik 2002, s. 68.

39 Sprawcą zerwania sejmiku był Kazimierz Głogowski, zob. Nacjonalny Gistoryczny Archiv Bielarusy Minsk, f. 695, op. 1, nr 142, k. 98, Szczęsny Potocki do króla, Sokal 12 [17?] XII 1694.

40 AGAD, APP, 163, t. 2, s. 567-568, Szczęsny Potocki, wojewoda krakowski do S. Szczuki, referendarza kor., Podhajce 26 VIII 1693.

${ }^{41}$ GStPK, I HA, Rep. 9, 27.m.2, k. 50, [Diariusz sejmu 1688/9].

${ }^{42}$ Akta sejmikowe województw poznańskiego i kaliskiego. Lata 1676-1695. Wyd. M. Zwierzykowski, R. KoŁodziej, A. Kamieński. Poznań 2018, s. 478. 
nie był jednak odosobniony, a narzekania na pracę marszałka Działyńskiego i deputatów do konstytucji były wówczas w kraju powszechne.

Przyglądając się pracom parlamentarnym Potockich w czasach Jana III Sobieskiego, rzuca się w oczy pewna różnica między posłami a senatorami z tegoż rodu, dotycząca ich aktywności politycznej. Jako posłowie Potoccy w żaden sposób się nie wyróżniali, na kartach diariuszy i relacji sejmowych informacje na ich temat pojawiają się sporadycznie. Nie widać ich w debatach sejmowych, nie są wymieniani jako kandydaci do funkcji marszałka. Mimo że dla wielu osób działalność polityczna i aktywność w izbie poselskiej były trampoliną do kariery, w przypadku Potockich chyba było inaczej. Pojawienie się na scenie największego theatrum Rzeczypospolitej, jakim był sejm, wiązało się z kilkoma celami, ale samo w sobie nie było głównym elementem budowania pozycji. Posłowanie było traktowane raczej jako element dodatkowy, z pewnością jednak nie najważniejszy. „Starożytnośćc rodu, zaplecze ekonomiczne w postaci dużych majątków, odpowiednie koligacje były to nieodzowne składowe, leżące u podstawy przyszłej kariery. Ich uzupełnieniem powinna być służba publiczna - udział w sejmikach, sejmach czy w pracach Trybunału. Posłowanie było również istotne dla budowania prestiżu w lokalnych strukturach władzy, dla wzbudzania szacunku u sąsiadów i współobywateli. Dlatego Potoccy posłowali wyłącznie z terenów wschodnich Rzeczypospolitej, nie starali się o mandaty poselskie z małopolskich sejmików wyżej usytuowanych w hierarchii opatowskiego czy proszowickiego. W przypadku rodu Potockich w omawianym okresie działalność polityczna była dobrze widzianym uzupełnieniem służby publicznej. Główną sferą działalności rodu była jednak armia i to dzięki niej Potoccy z czasów Jana III robili przyszłe kariery. Większość z nich to wszakże żołnierze, którzy dzięki toczącej się wojnie mieli okazję wykazać się i zasłużyć na wdzięczność króla i Rzeczypospolitej. A to przynosiło profity, również w postaci awansów. $\mathrm{Z}$ wymienionych $\mathrm{w}$ artykule dziesięciu osób, piastujących przynajmniej raz funkcję poselską, aż sześć otrzymało w późniejszym czasie nominacje senatorskie, jedna (Józef Felicjan) zatrzymała się na strażnikostwie koronnym, jednej (Stanisław Potocki) karierę przerwała przedwczesna śmierć w bitwie pod Wiedniem. Wzbogacenie swego życiorysu o funkcję poselską było dla Potockich istotne, ale z pewnością nie decydujące w zdobywaniu kolejnych szczebli awansu społecznego. Mandat posła nie był celem samym w sobie, ale krokiem do budowania pozycji, zarówno w skali całego kraju, jak i w lokalnym środowisku.

Pozornie nieco inaczej przedstawia się sytuacja w przypadku Potockich senatorów, choć oczywiście wnioski należy wyciągać dość ostrożnie ze względu na fakt, że badana jest grupa zaledwie dwuosobowa. Obaj Potoccy — Jędrzej i Feliks — starali się uczestniczyć w procesie decyzyjnym w kwestii zwołania sejmu, udzielając królowi odpowiedzi na deliberatoria, niekiedy bardzo obszernych. Pracowali dla króla (choć pewnie bardziej dla swego rodu) na sejmikach i aktywnie uczestniczyli też w sejmach, a jeśli wygłaszali wota, to były to mowy zawierające bardzo interesujące 
spostrzeżenia, propozycje i postulaty reformatorskie. Nie można jednak oprzeć się wrażeniu, że mimo aktywnego życia politycznego, udziału w sejmach i sejmikach, obaj bracia Potoccy gros swoich działań poświęcali sprawom wojskowym i to było zapewne głównym motorem napędowym ich karier ${ }^{43}$. Późne przyjazdy na sejmy czy nieobecność na sejmach grodzieńskich po części wynikała zapewne z obowiązków związanych z działalnością w wojsku. Aktywność polityczna była na pewno konieczna, po części mogła jednak wynikać z żądań stawianych przez króla. Najważniejsze jednak, że dobry kontakt z monarchą z pewnością ułatwiał kariery rodzinie, a wpływy na sejmikach przyczyniały się do uzyskiwania godności poselskich zarówno przez synów Jędrzeja i Feliksa, jak i innych krewnych z rodziny Potockich. A to przekładało się na możliwości ich dalszej kariery, budując podwaliny potęgi rodu w XVIII wieku.

\section{Bibliografia}

Akta sejmikowe województwa podolskiego in hostico 1672-1698. Wyd. J. STOLICKI. Kraków 2002.

Akta sejmikowe województw poznańskiego i kaliskiego. Lata 1676-1695. Wyd. M. ZWIERZYKowsKi, R. KoŁodziej, A. Kamieński. Poznań 2018.

CzARniecka A.: Nikt nie stucha mnie za życia... Jan III Sobieski $w$ walce $z$ opozycyjna propagandq (1684-1696). Warszawa 2009.

DzIĘGIELEWsKi J.: Izba poselska $w$ systemie władzy Rzeczypospolitej w czasach Władysława IV. Warszawa 1992.

Górna B.: Antykrólewska propaganda opozycji (od bitwy wiedeńskiej do sejmu 1685 roku). „Śląski Kwartalnik Historyczny Sobótka” 1996, 51, nr 1-3, s. 147-152.

KoŁOdZIEJ R.: „Ostatni wolności naszej klejnot”. Sejm Rzeczypospolitej za panowania Jana III Sobieskiego. Poznań 2014.

Link-Lenczowski A.: Potocki Józef Felicjan h. Pilawa (zm. 1723). W: Polski słownik biograficzny. T. 28. Wrocław 1984-1985, s. 58-59.

Link-Lenczowski A.: Potocki Stefan h. Pilawa (zm. 1726). W: Polski słownik biograficzny. T. 28. Wrocław 1984-1985, s. 177-180.

Link-Lenczowski A., Szklarska E.: Potocki Michat (zm. 1749). W: Polski słownik biograficzny. T. 28. Wrocław 1984-1985, s. 97-101.

Nagielski M.: Potocki Pawet h. Pilawa (zm. 1675). W: Polski słownik biograficzny. T. 28. Wrocław 1984-1985, s. 119.

NiesieCKi K.: Herbarz polski. T. 7. Wyd. J.N. BobrowiCz. Lipsk 1841.

Ochmann-StAniszewska S., Staniszewski Z.: Sejm Rzeczypospolitej za panowania Jana Kazimierza Wazy. Prawo - doktryna - praktyka. Wrocław 2001.

Pomniki dziejów Polski wieku siedemnastego. T. 1. Wyd. A. Podgórski. Wrocław 1840.

${ }^{43}$ Obaj bracia mieli wydzielone pułki wojska w armii koronnej, ich komputy zob. P. SMOLAREK: Kampania mołdawska Jana III roku 1691. Do druku przyg. Z. Hundert, M. WAGner. Oświęcim 2015, s. 90-97. 
Posłowie ziemscy koronni 1493-1600. Red. I. KAnIEwsKA. Warszawa 2013.

Przy воś A.: Potocki Dominik h. Pilawa (zm. 1683). W: Polski słownik biograficzny. T. 27. WrocławWarszawa 1983, s. 803.

Sarnecki K.: Pamiętniki z czasów Jana Sobieskiego. Diariusz i relacje z lat 1691-1696. Oprac. J. WolińsKi. Wrocław 1958.

Smolarek P.: Kampania mołdawska Jana III roku 1691. Do druku przygotowali Z. Hundert, M. WAGNER. Oświęcim 2015.

SтоLіскі J.: Wobec wolności i króla. Działalność polityczna szlachty ruskiej, ukrainnej i wołyńskiej w latach 1673-1683. Kraków 2007.

Urzędnicy województwa kijowskiego i czernihowskiego XVI-XVIII wieku. Spisy. Oprac. E. Janas, W. KŁACZEWSKI. Kórnik 2002.

Volumina Legum. T. 5. Wyd. J. Oнryzкo. Petersburg 1860.

Wagner M.: Potocki Stanisław h. Pilawa (1659-1683). W: Polski słownik biograficzny. T. 27. Wroclaw-Warszawa 1983, s. 153-154.

Wierzbicki L.A.: Marszałkowie i parlamentarzyści. Studia z dziejów sejmu polskiego w XVII wieku. Warszawa 2014.

Robert Kołodziej

Participation of the Potockis in Sejm proceedings
during the reign of John III Sobieski

Summary

Since the beginning of the 17th century the gens Potocki enjoyed their growing significance in the Polish-Lithuanian Commonwealth. It translated into ever more frequent taking and holding by them state offices and functions, including the ones of MPs. What could now be estimated is that during the reign of John III Sobieski as many as ten Potockis held a seat in Sejm. The most experienced among them was Stefan Potocki, who served four terms. The remainder of the mentioned representatives include persons who served a few terms. Overall, the Potockis held the office of MP 27 times. However, their activity as MPs was not too impressive, which is corroborated by few and far between mentions about them in parliamentary minutes. More active seem to have been the senators originating from the gens Potocki, namely brothers Jędrzej and Feliks, yet the said activity might have stemmed from the King's expectations. They partook in pre-Sejm dietines and relatively frequently were present during Sejm sessions. Their senate advisory speeches (Polish wota senatorskie) did not consist of hot-air rhetoric, but included helpful comments on state of the commonwealth. It may seem, however, that both for MPs and for senators coming from the family Potocki the military service was paramount, and the political activity merely complemented it.

Key words: gens Potocki, John III Sobieski, MP, dietines 